\title{
THE EFFECTIVENESS OF CHUNKING STRATEGY IN DEVELOPING STUDENTS' ABILITY OF STORY RETELLING
}

\author{
Rohmaniyah \& Nur Ekaningsih \\ Universitas Islam Sultan Agung
}

\begin{abstract}
This research aims at finding out whether or not the use of chunking strategy is effective in developing students' ability of story retelling to the tenthgrade students at MAN 01 Pekalongan. Quasi experimental research was applied as the method with two groups : experimental and control group. The total subject of this research was 52 students which were taken from two classes of X IPS 1 as a control group and X AGAMA 2 as an experimental group. Face and content validity were done by asking the English teacher and advisor to be expert judgements to validate the instrument by using a rubric appearance of test for face validity and its conformity by curriculum as a content validity. Inter-rater reliability in giving scores to the students' was done to measure the reliability of the test. This research used SPSS in analysing the data of speaking test through several activities. They were pre-test before treatments, and post-test after treatments. The result of the research shows the significant difference in the story retelling ability between tenth grade students who were taught by using chunking strategy and those were not taught by using it. It can be seen in the result of mean score in the post-test of experimental class which is 89 and control class which is 83 and as a result Sig. (2-tailed) is $0.044<0.050$. Therefore, the null hyothesis of this study is rejected. It means that the use of chunking strategy had significantly improved the tenth-grade students story retelling ability in English teaching and learning process of the experimental class at MAN 01 Pekalongan in the academic year 2019/2020.
\end{abstract}

Key words: chunking, teaching speaking strategy, story retelling

\section{INRODUCTION}

One of the four language skills used for achieving many purposes in learning English is speaking. The purposes of it are such as having a social contact with other people, having a discussion over a subject, having an informal conversation, and the important one it may aim to express opinions, according to Richard \&Renandya (2002) cited in Zafarghandi, et al (2015).

Speaking as a media of communication is very beneficial in language teaching and learning. As stated in Ekaningsih, N (2017), creating condition with full of supporting environment to speak English proved students' familiarities to be free discussing. This means that the school's language teacher should create appropriate condition to make students speak English fluently and well. The way how to do it will depend on teachers' models of teaching speaking in classroom 
activities. The teacher's model of teaching can be applied in the classroom with some supported and related materials.

There are two kinds of teaching materials in English language learning, which are compulsory English material and supplementary English material. Those have theirownfocuses. Compulsory English material focuses on the applying language as a communication instrument. Besides, supplementary English material focuses not only on applying language as a communication instrument but also on the ability of students in appreciating literature things in English. Speaking skill is the second of the four language skills taught in schools. Those are included as aspects of the compulsory English material. Speaking is a mutual process of building connotative which includes creating, accepting, and altering information in field of language (Brown, 1994; Burns \& Joyce 1997, cited in Nuraini, 2016). A product of speaking constitutes communication unless what is said is comprehended by listeners. Therefore, speaking skill requires seriousness and sincerity in terms of learning.

In the process of communication, the speakers of a language should have knowledge of the pattern of language they use. Many teachers rarely don't pay attention to the problems in teaching speaking. Teachers are rarely use any variation of teaching strategies in their english teaching learning. Some of them still use stagnant strategies, such as using textbook only in their english teaching, using a teacher-centered model which is teacher is the only center to learn pronunciation, fluency, accuracy in the teaching learning process of English class.

Helping students develop their ability in the speaking skill which focuses on the story retelling activity, teachers should cary out attractive and charming strategy. One of strategies is applying chunking in story retelling activity. Furthermore, chunking reflects to the action of cracking word into bite-sized chunk to easily brief new word into the mind. Inside of mind requires supports in order to build up long memory which is where people manage words, maintain word at one time (Malamed, 2012). Through this way, the students are more able to produce the objective language. They will mastery speaking skill especially story retelling in a memorable way and communicative way.

The explanations tells that the researcher will handle a study entitled "The effectiveness of chunking strategy in developing students' ability in story retelling". This research aims to help English teachers develop the students' ability in story retelling and to help the students reach the purposes of their learning English.

\section{Definition of Chunking}

According to Richards (2008) in Mohammadi (2018), when communicate people will carry a lexical arrangement of connection based on the mastering glossary and recollected chunks of language. It means that chunking affects students' speaking skills and activities. By chunking strategy, students will easily express their messages or information to another. Some other researcher also stated that Chunking a process of performing information naturallyby dividing them into shorter information items(Valentine, 2014). 
The theory of chunking was proposed by Miller in the year of 1956. Miller annalyzed that plenty of focus in the theory of short style consciousness and its practical characteristics. Then, chunking becomes one of important factors in developing students ability in story retelling. Chunking consists of two techniques : the sequence of units in a chunk and selection of the chunks. In conclusion chuking strategy refers to the hierarical approach of noncognitive, cognitive, social activity in language process. (Michael, 2014)

On the other hand, many researchers investigate the chunking strategy, as one of the findings of McCarty and Carter (2002) were along with what Zafarghandi, et al. (2017) stated that the significance of multi chunks for the concept of fleuncy. Understanding chunking words could support learners in developing their ability in speaking skill especially in story retelling activity.

\section{The Chunking Strategy}

As stated by Attar and Allami (2013), chunking strategy can manage the English speaking ability and assimilate knowledge in story retelling ability by some steps below:

- by memorizing, this first step is the focus of the chunking strategy, by this step students could get the chunk word and produce speaking product easily, especially in the story retelling ability.

- by imitating, in the second step students could imitate the chunk word they memorized, then they will remember the speaker saying by imitating the chunk words.

- By practicing, in the last step is the key step, students will apply the chunk words they memorized, then remind it by imitating the chunk words they memorized, after that they apply it into practicing the chunk words.

It can be concluded that chunking strategy by applying those three step may help students in developing students' ability in the speaking activities especially in the story retelling ability.

\section{The Advantages of Chunking}

Stated by Zafarghandi, et al. (2017), some of benefits of applying chunking strategy in the classroom activity, are :It can help students to catch clearly what information by appropriate pause, tone, power, speed of speech, and chunk words delivered by speakers. It can develop students' fluency in speaking English. And increase creativity thinking skill to help students arrange and create speaking product.

Furthermore, Movahediyan Attar and Allami (2013) explained that the effects of using chunking strategy in the story retelling is to examine the relationship between students' knowledge and the use of chunking in their story retelling process. 


\section{Definition of Teaching Speaking Strategy}

As far as stated by Alfi (2015) it is a detailed list of rules or guidelines for teaching speaking activities. Thus speaking strategies include the activities practices and social which operate in teaching speaking based on some strategies. Furthermore, Anthony (1963: 96) cited in Silva (2013) says that the strategyin the teaching-learning process is important because sometimes students get bored and frustrated in the classroom. Then, that condition can make them lose their concentration about the lesson taught by the teachers. So, teachers need to use the strategy in the teaching learning process since it can facilitate learners to be easier in achieving the knowledge given by the teacher especially in the speaking activities teachers have to make students always speak up and avoid boredom. Based on Alfi (2015) teaching speaking to students of EFL aims to produce English conversation sounds native although they do not focus on the grammatical pattern, furthermore, it also aims to use proper word, sentences, intonation, pronunciation, expression, and patterns.

\section{Story Retelling}

Retelling as stated by (Irwan, 2016) is product of finishing reading and listening ability about a story in side of readers and listeners tell what they catch their mind from what they read or listen. Story retelling builds opportunity expansion ideas of the presenter or story teller. Furthermore, as stated by other researcher, story retelling is sharing orally story of individual or traditional story by using the main of the tradition from which it comes. It chances in expressing ideas in the mind using descriptive language, or story teller own words. And it also offers natural language experiences for students (Aldilah, 2018). It may be concluded that story retelling is one of way in expressing story orally what the story teller remember and what comes in the mind.

\section{Relation between Story Retelling and Improving Speaking}

Story retelling becomes one of the oldest activities in speaking, it aims to stimulate the learners in enjoying speaking activities. Furthermore, Brown stated some of types in classroom such as conterfeit, comprehensive, receptive, dialogue conversation, interpersonal (dialogue), monologue, other bilateral strategies like games, presentation, interviews, jigsaw, role-play, discussion, and others.

It is considered that is one of activities which elaborates to the speaking activity. Story retelling is an activity which includes a storyteller, and viewers, so that students will be either speaker or viewer. They have to retell their story and give feedback from another stories.

\section{METHOD}

The research method in this study was an experimental research approach to find the effect of chunking strategy in developing student's ability in story retelling. The subject of this study was tenth grade students of MAN 01 Pekalongan. There were 52 students which divided into two groups, control and experimental group. In this study, used test for the instrument tools. This study 
used speaking test as the instrument. There were pre-test and post test used by both experimental and control groups. For the try out instrument test, the students had to listen carefully the example of story which given in the class, then students had to read the story which given by the teacher in the class, after that the students had to memorize the story which given by the teacher in the class, and the last students had to speak the story up or retell the story which given by the teacher in the class.For the pre-test instrument test, the students had to listen carefully the example of story which given in the class, after that the students had to read the story which given by the teacher in the class, then the students had to memorize the story which given by the teacher in the class, and then at the last instruction was the students had to speak the story up or retell the story which given by the teacher in the class. For the post-test instrument test, actually the same instruction with the pre-test and try out test instructions, but that made it different was the text given in the instrument test paper for each try out test, pre-test, and post-test. But, exactly the writer drawn the post-test instructions as below :

- Teacher asked students to come in front of the teacher individually.

- Teacher provided students a test paper for students who came in front.

- Teacher instructed students to made a slash or decided the chunk words in the text test.

- Teacher asked students to applied the chunking strategy which be told by spoken.

- Teacher asked students to memorized the text given.

- Teacher asked students to spoke up the text by memorizing and applying chunking strategy in story retelling class.

After collecting data of all the students, then those data compared between the experimental and control group. It aims to establish whether using chunking as a strategy creates significant improvement on students' ability in story retelling or not. The data had been analyzed by using statistical computation in this case used SPSS Program. Two tests used to analyze the data. Before doing test, there were some requirements that had been completed such as standard normality and standard homogeneity. To analyze the standard normality of the data, this study used one simple Kolmogorov-Smirnov test in SPSS program.

\section{FINDINGS AND DISCUSSION}

Analyzing the normality of the data is important, in order to balance between the test given in the control and experimental class. The result of the pretest by using Kolmogorov-Smirnov Test from SPSS program as follows: 
PROMINENT Journal, Volume 3, Number 2, July 2020

One-Sample Kolmogorov-Smirnov Test

\begin{tabular}{llcc}
\hline & & pretest_experimental & pretest_control \\
\hline $\mathrm{N}$ & & 23 & 29 \\
Normal & Mean & 83.09 & 78.62 \\
Parameters & & \\
& Std. & 10.492 & 9.221 \\
Most Extreme & Deviation & .223 & .146 \\
Differences & Absolute & .172 & .122 \\
& Positive & -.223 & -.146 \\
Kolmogorov-Smirnov Z & 1.071 & .785 \\
Asymp. Sig. (2-tailed) & .202 & .569 \\
\hline
\end{tabular}

a. Test distribution is Normal.

b. Calculated from data.

The analysis of normality data of pre-test both control and experimental class used Kolmogorov-Smirnov test was 0.785 with Sig. (2-tailed) $0.569>0.05$, on the opposite class of Kolmogorov-Smirnov test score of experimental class was 1.071 with Sig. (2-tailed) $0.202>0.05$. It means that all samples based on both control and experimental class were normal.

The Histogram of the Pre-Test score in Control Group

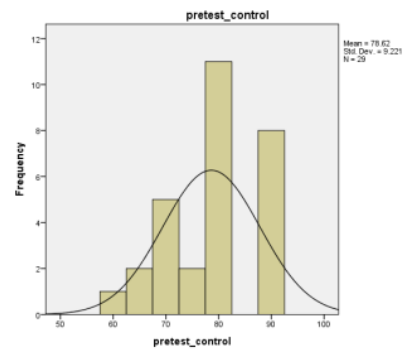

The Histogram of the Pre-Test score in Experimental Group

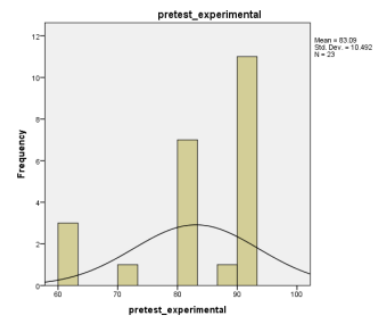


PROMINENT Journal, Volume 3, Number 2, July 2020

Independent Samples Test

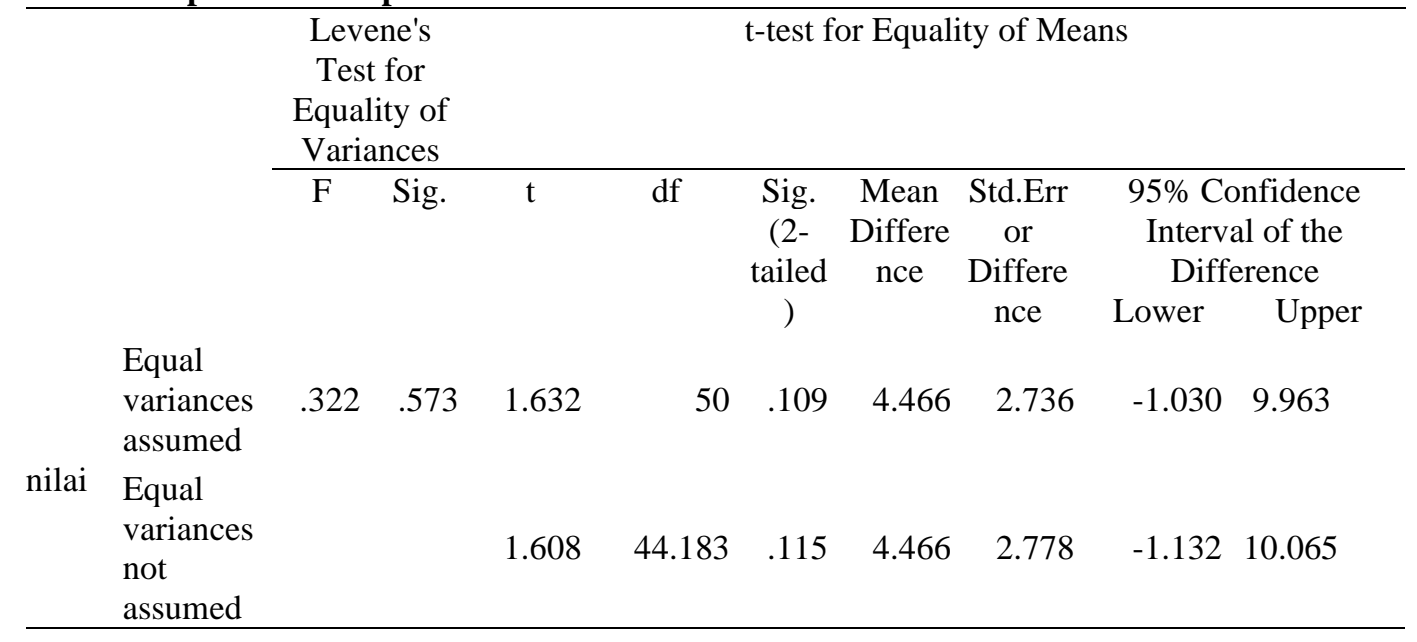

The result of the independent sample test of Pre-test shows that the Sig. (2tailed) was $0.109>0.05$. It means that there was no significant differences between the mean score of control and experimental group in pre-test. Therefore, it was important to do treatment.

The treatment did in six meetings, 2 meetings for the opening, 2 meetings for the deep practice and 2 meetings rest for the tests.

\begin{tabular}{llrr}
\multicolumn{4}{c}{ One-Sample Kolmogorov-Smirnov Test } \\
\hline & & posttest experimental & posttest control \\
\hline $\mathrm{N}$ & & 23 & 29 \\
\multirow{2}{*}{ Normal Parameters ${ }^{\mathrm{a}, \mathrm{b}}$} & Mean & 89.09 & 83.07 \\
& Std. Deviation & 8.273 & 12.601 \\
\multirow{2}{*}{ Most Extreme Differences } & Absolute & .160 & .135 \\
& Positive & .094 & .090 \\
Kolmogorov-Smirnov Z & Negative & -.160 & -.135 \\
Asymp. Sig. (2-tailed) & & .768 & .727 \\
\hline
\end{tabular}

a. Test distribution is Normal.

b. Calculated from data.

Test score of control group in post-test was 0.727 with Sig. (2-tailed) 0.666> 0.05 , while Kolmogorov-Smirnov Test score of experimental group in post-test was 0.768 with Sig. (2-tailed) 0.597> 0.05. It means that all samples based on both experimental and control class were normal. For the curves as below:

The Histogram of the Post-Test score in Control Group

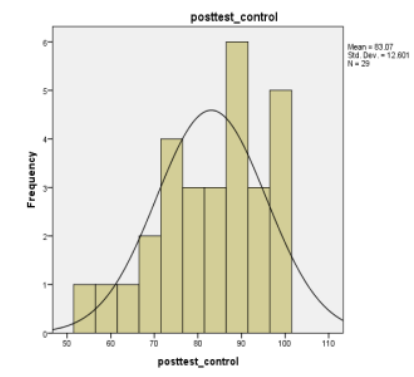


The Histogram of the Post-Test score in Experimental Group

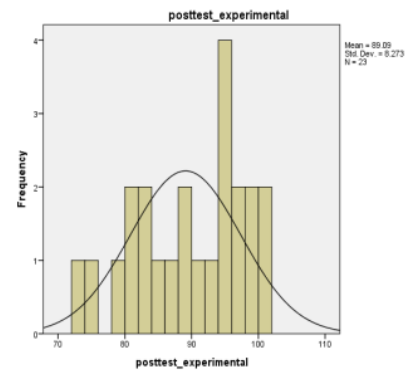

Independent Samples Test

\begin{tabular}{|c|c|c|c|c|c|c|c|c|c|c|}
\hline & & \multicolumn{2}{|c|}{$\begin{array}{l}\text { Levene's Tes } \\
\text { for Equality o } \\
\text { Variances }\end{array}$} & \multicolumn{3}{|c|}{ t-test for Equality of Means } & \multirow[b]{2}{*}{$\begin{array}{l}\text { Mean } \\
\text { Differe } \\
\text { nce }\end{array}$} & \multirow[b]{2}{*}{$\begin{array}{l}\text { Std. } \\
\text { Error } \\
\text { Differe } \\
\text { nce } \\
\end{array}$} & \multirow{2}{*}{\multicolumn{2}{|c|}{$\begin{array}{l}\text { 95\% Confidence } \\
\text { Interval of the } \\
\text { Difference } \\
\text { Lower Upper }\end{array}$}} \\
\hline & & $\bar{F}$ & Sig. & $\mathrm{t}$ & df & $\begin{array}{l}\text { Sig. } \\
(2- \\
\text { tailed })\end{array}$ & & & & \\
\hline \multirow[b]{2}{*}{ Nilai } & $\begin{array}{l}\text { Equ } \\
\text { al } \\
\text { vari } \\
\text { ance } \\
\text { s } \\
\text { assu } \\
\text { med }\end{array}$ & 4.259 & .44 & 1.976 & 50 & .054 & 6.018 & 3.046 & -.101 & 12.137 \\
\hline & $\begin{array}{l}\text { Equ } \\
\text { al } \\
\text { vari } \\
\text { ance } \\
\text { s } \\
\text { not } \\
\text { assu } \\
\text { med }\end{array}$ & & & 2.070 & 48.481 & .044 & 6.018 & 2.907 & .174 & 11.862 \\
\hline
\end{tabular}

The result of independent test of post-test both control and experimental group that Sig. (2-tailed) was $0.044<0.05$. It means that $\mathrm{H} 0$ was rejected and $\mathrm{Ha}$ was accepted. Then, it can be concluded that the use of chunking strategy in developing students ability in story retelling is effective to be practicedin teaching speaking strategy.

The aim of doing the test was to know the effectiveness of using chunking strategy in developing students ability in story retelling for tenth grade students of MAN 01 Pekalongan in the academic year 2019/2020. The average score of control group in the pre-test was 78 whereas the experimental group was 83, so it could be concluded that the ability of two groups was almost the same. After the treatment given in the experimental class, the average score of control group was lower than the experimental group. In post-test, the control group got 83, while for the experimental group got 89 . So, there were different gain score between the 
average score of both group result post-test minus pre-test. In experimental group got 6 and for the control group got 5. From the post-test scores it could be concluded that the average score of experimental group in post-test was better than the score of control group. As a result, that Sig. (2-tailed) was $0.044<0.005$, which means that $\mathrm{H} 0$ was rejected and $\mathrm{Ha}$ was accepted. In this case of treatment, actually, the researcher got a good class level both control and experimental class. It doesn't matter that the result still concludes that teaching strategy by using chunking is effective. Furthermore, there were some addition reasons based on students' responses, that they were so interested and easy to communicate by using chunking strategy. Chunking helps them in memorizing the chunk words then helps them to communicate by chunk words they memorized, then produce a fluent speaking production.

The fact that speaking class is boring for many students requires teacher to give motivation and stimulate them. Appropriate teaching strategy could influence students to be interested in speaking and chunking could be an alternative strategy for teachers in teaching speaking not only in story retelling but in other kinds of speaking skill.

\section{CONCLUSION AND SUGGESTION}

Based on statistical data, the students' mastery of story retelling using chunking strategy develop after the treatment given. It supported by the differences in the result of the average score of the control and experimental group. The average score of the experimental group after given the treatment was 89 , and the eaverage score of control group was 83 . There were different score between average score of both groups, in addition the result of post-test minus pre-test in experimental group got 6 and for the control group got 5. It supported by the Sig.(2-tailed) that $0.004<0.05$ which means that $\mathrm{H} 0$ was rejected and $\mathrm{Ha}$ was accepted. As a result teaching speaking by using chunking strategy develops their story retelling ability. It could be concluded that the use of chunking strategy in developing student's ability in story retelling is effective. Therefore, it could help students' development at tenth grade students of MAN 01 Pekalongan in the academic year of 2019/2020.

\section{REFERENCES}

Abel, G. M. (2017). Effective Teaching and Learning Strategies in Science and Mathematics to Improve Students Academic Performance in Nigeria. 1-7.

Aldilah. (2018). The Effectiveness of Story Retelling and Story Reading Methods in Teaching Speaking. ETERNAL, 3-19.

Alvi. (2016). A Manual for Selecting Sampling Techniques in Research. Research gate

Ary, D., Jacobs, L. C., Sorensen, C., \& Razavieh, A. (2010). Introduction to Researchin Eduction. (C. Shortt, Ed.) (8th ed.). Belmont: Wadsworth Cengage Learning. 
PROMINENT Journal, Volume 3, Number 2, July 2020

Brown, H.D. (2004). Language Assessment: Principles and Classroom Practices. San Francisco: Longman

C, S. (2017).Research Design-The New Perspective of Research Methodology. British Journal of Education, Society, and Behavioural Science .

Cohen, L. (2000). Research Methods in Education. (5th edition). London: Routledge Fahner

Efrizal.(2012). A review of EFL Learners' Speaking Skill and The Strategies for Improvement. Researchgate .

Erba, T. L. (2017). Sampling Methods and Sample Populations in Quantitative Mass Communication Research Studies. Researchgate , 42-47.

Ghazali. (2011).Aplication of Multi Variate Analysis with SPSS Program. Semarang: Diponegoro University Publishing Agency.

Intan, A. (2015).Improving Students Speaking Skills Through Communicative Games. Jogjakarta.

Inten. (2016). The Effectiveness of Using Storytelling Technique on Students' Speaking Skill. Jakarta: UIN Syarif Hidayatullah.

Irwan. (2016). The Effect of Retelling Story Towards Students' Speaking Ability. ENGEDU , 13-28.

Issac, Jerin C. (2010). Methods and Strategies of Teaching: an overview. Pondicherry University Press.

Kaur SP. (2013). Variables in Research. IJRRMS, 3.

Masbiran, F. \&. (2017). Speaking Skill in Using Community Language Learning. IJIELT .

Mohammadi, E. (2018). The Effects of Lexical Chunks Teaching on EFL Intermediate Learners' Speaking Fluency. International Journal of Instruction , 179-192.

Nur, E. (2017). English Speaking Learning Management Conducted by Nonnative Junior High School Students with International Curriculum Semarang Regency. ELIC, 563-574.

Prasko. (2015). Baic Method of Research. SAGF Journlas. 
PROMINENT Journal, Volume 3, Number 2, July 2020

Rogatcheva, S. (2014). Aspect in learner speaking : a corpus-based comparison of advanced Bulgarian and German learners' spoken English.

Seltman, M. (2017).Experimental Design and Analysis. Researchgate .

Silva. (2013). Improving Students' Speaking Skills Through The Use of Video Clip. Yogyakarta.

Taherdoost. (2016). Sampling Methods in Research Methodology : How to Choose A Sampling Technique for Research. Researchgate , 1-10.

Ulkervenera. (2017). The Design and Use of Speaking Assesment Rubrics.ILSTE.

Valentine, M. \&. (2014). Chunking Dynamics : Heteroclinics in Mind. Researchgate, 11.

Walliman. (2011). Research Method: The Basics. Researchgate .

Zafarghandi, T. B. (2015). The Impact of Teaching Chunks on Speaking Fluency of Iranian EFL Learners. IJEAP , 36-47. 